\title{
Glucose, palmitate and pro-inflammatory cytokines modulate production and activity of a phagocyte-like NADPH oxidase in rat pancreatic islets and a clonal beta cell line
}

\author{
D. Morgan $\cdot$ H. R. Oliveira-Emilio $\cdot$ D. Keane $\cdot$ \\ A. E. Hirata • M. Santos da Rocha • S. Bordin • R. Curi • \\ P. Newsholme • A. R. Carpinelli
}

Received: 27 March 2006 / Accepted: 21 August 2006/Published online: 7 December 2006

(C) Springer-Verlag 2006

\begin{abstract}
Aims/hypothesis Acute or chronic exposure of beta cells to glucose, palmitic acid or pro-inflammatory cytokines will result in increased production of the $\mathrm{p} 47^{\text {phox }}$ component of the NADPH oxidase and subsequent production of reactive oxygen species (ROS).

Methods Rat pancreatic islets or clonal rat BRIN BD11 beta cells were incubated in the presence of glucose, palmitic acid or pro-inflammatory cytokines for periods between 1 and 24 h. p4 $7^{\text {phox }}$ production was determined by western blotting. ROS production was determined by spectrophotometric nitroblue tetrazolium or fluorescencebased hydroethidine assays.

Results Incubation for $24 \mathrm{~h}$ in $0.1 \mathrm{mmol} / 1$ palmitic acid or a pro-inflammatory cytokine cocktail increased $\mathrm{p} 47^{\text {phox }}$ protein production by 1.5 -fold or by 1.75 -fold, respectively, in the BRIN BD11 beta cell line. In the presence of $16.7 \mathrm{mmol} / \mathrm{l}$ glucose protein production of $\mathrm{p} 47^{\text {phox }}$ was increased by 1.7 -fold in isolated rat islets after $1 \mathrm{~h}$, while in the presence of $0.1 \mathrm{mmol} / 1$ palmitic acid or $5 \mathrm{ng} / \mathrm{ml} \mathrm{IL}-1 \beta$ it was increased by 1.4 -fold or 1.8 -fold, respectively. However,

D. Morgan and H. R. Oliveira-Emilio contributed equally to this study.

D. Morgan · H. R. Oliveira-Emilio · A. E. Hirata •

M. Santos da Rocha $\cdot$ S. Bordin $\cdot$ R. Curi $\cdot$ A. R. Carpinelli $(\triangle)$

Department of Physiology and Biophysics,

Institute of Biomedical Sciences, University of São Paulo,

Av. Prof. Lineu Prestes, 1524,

05508.900 São Paulo, Brazil

e-mail: angelo@icb.usp.br

D. Keane $\cdot$ P. Newsholme $(\triangle)$

School of Biomolecular and Biomedical Sciences,

Conway Institute, UCD Diabetes Research Centre,

University College Dublin,

Belfield, Dublin, Ireland

e-mail: philip.newsholme@ucd.ie
\end{abstract}

palmitic acid or IL-1 $\beta$-dependent production was reduced after $24 \mathrm{~h}$. Islet ROS production was significantly increased after incubation in elevated glucose for $1 \mathrm{~h}$ and was completely abolished by addition of diphenylene iodonium, an inhibitor of NADPH oxidase or by the oligonucleotide anti-p $47^{\text {phox }}$. Addition of $0.1 \mathrm{mmol} / 1$ palmitic acid or $5 \mathrm{ng} / \mathrm{ml}$ IL-1 $\beta$ plus $5.6 \mathrm{mmol} / 1$ glucose also resulted in a significant increase in islet ROS production after $1 \mathrm{~h}$, which was partially attenuated by diphenylene iodonium or the protein kinase C inhibitor GF109203X. However, ROS production was reduced after $24 \mathrm{~h}$ incubation.

Conclusions/interpretation NADPH oxidase may play a key role in normal beta cell physiology, but under specific conditions may also contribute to beta cell demise.

Keywords Beta cells $\cdot$ Cytokines $\cdot$ Glucose .

NADPH oxidase $\cdot$ Palmitate $\cdot$ Pancreatic islets .

Protein production $\cdot$ ROS production

$\begin{array}{ll}\text { Abbreviations } \\ \text { DPI } & \text { diphenylene iodonium } \\ \text { GAPDH } & \text { glyceraldehyde-3-phosphate dehydrogenase } \\ \text { GF109203X } & \text { bysindoylmaleimide } \\ \text { HEt } & \text { hydroethidine } \\ \text { NBT } & \text { nitroblue tetrazolium } \\ \text { PKC } & \text { protein kinase C } \\ \text { ROS } & \text { reactive oxygen species }\end{array}$

\section{Introduction}

An increase in blood glucose concentration is the most important regulatory stimulus for pancreatic beta cell insulin secretion. In addition to glucose, other nutrients 
are also important regulators of insulin secretion, e.g. NEFA. Palmitate, one of the most abundant NEFA in plasma, acutely potentiates glucose-stimulated insulin secretion by beta cells, but chronically reduces it. The metabolic interaction between glucose and palmitate may generate lipid intermediates (diacylglycerol, phosphatidylserine) that activate specific isoforms of protein kinase $\mathrm{C}$ (PKC), thereby enhancing insulin secretion $[1,2]$. Indeed, it was recently demonstrated [3] that long-chain fatty acylCoA, mainly palmitoyl-CoA, potentiated glucose-stimulated insulin secretion in clonal beta cells through PKC activation.

Many studies have now shown the expression and activity of phagocyte-like NADPH oxidase in non-phagocytic cells [4-6]. The NADPH oxidase consists of six hetero-subunits, which associate in a stimulus-dependent manner to form the active enzyme complex and produce superoxide. Tight regulation of enzymatic activity is achieved by two mechanisms; separation of the oxidase subunits into different subcellular locations during the resting state (cytosolic and membrane-bound), and modulation of reversible protein-protein and protein-lipid interactions. These can either promote the resting state or allow translocation to the membrane in response to appropriate stimuli. Two NADPH oxidase subunits, gp $91^{p h o x}$ and $\mathrm{p} 22^{\text {phox }}$, are integral membrane proteins. They form a heterodimeric flavocytochrome b558 that forms the catalytic core of the enzyme, but exist in the inactive state in the absence of the other subunits. The additional subunits are required for regulation and are located in the cytosol during the resting state. They include the proteins $\mathrm{p} 67^{\text {phox }}$, $\mathrm{p} 47^{\text {phox }}$ and $\mathrm{p} 40^{\text {phox }}$ as well as the small GTPase Rac. $\mathrm{p} 47^{\text {phox }}$ is phosphorylated at multiple sites by a number of protein kinases including members of the PKC family, and as such plays the most important role in the regulation of NADPH oxidase activity $[7,8]$.

Recently, we demonstrated the expression and activity of a phagocyte-like NADPH oxidase in pancreatic islets [9]. The expression of NADPH oxidase components was demonstrated by RT-PCR (gp91 phox, $\mathrm{p} 22^{\text {phox }}$ and $\mathrm{p} 47^{\text {phox }}$ ) and western blotting ( $\mathrm{p} 47^{\text {phox }}$ and $\mathrm{p} 67^{\text {phox }}$ ). We also found that glucose-stimulated production of reactive oxygen species (ROS) in pancreatic islets occurred by PKCdependent activation of NADPH oxidase. This finding is similar to a report that high glucose and PKC mediated activation of NADPH oxidase and ROS production in mesangial cells [10]. Recently, it was reported [11] that glibenclamide (one of a class of clinically important insulin secretagogue drugs known as sulfonylureas) stimulated ROS production in a pancreatic beta cell line (MIN6 cells) through NADPH oxidase.

In pathological conditions leading to type 2 diabetes it is known that elevations of glucose and NEFA levels induce production of ROS in beta cells $[12,13]$. It has been reported that a major source of ROS is the mitochondrion, in which increased availability of substrates causes enhanced oxidative activity and production of oxygen derivatives $[12,13]$. However, we speculate that a major source of superoxide is the NADPH oxidase system, which may be upregulated in the presence of saturated NEFA, or indeed of proinflammatory cytokines, which are known to increase production of components of the NADPH oxidase system in the phagocytic cells of the immune system $[14,15]$.

Others have recently reported that nutrients (such as high levels of glucose and palmitate) stimulated cultured aortic smooth and endothelial cell phagocyte-like NADPH oxidase via PKC-dependent activation [16], while a very recent study demonstrated increased production of the NADPH oxidase components gp91 phox and $\mathrm{p} 22^{\text {phox }}$ in beta cells obtained from animal models of type 2 diabetes [17]. However, in spite of this information, a systematic study on the effect of glucose, palmitate or pro-inflammatory cytokines (major positive or negative insulin secretion regulators) on NADPH oxidase production and activation in pancreatic beta cells has not been reported. Thus we investigated the effects of glucose, palmitate or IL-1 $\beta$ on the production of $\mathrm{p} 47^{\text {phox }}$ and activation of NADPH oxidase in isolated primary rat pancreatic islets. In addition, we used the glucose-responsive clonal rat pancreatic insulin-secreting cell line, BRIN BD11, to analyse production of $\mathrm{p} 47^{p h o x}$ after exposure to the saturated fatty acid palmitate, or a pro-inflammatory cytokine cocktail.

\section{Materials and methods}

\section{Materials}

All chemicals for buffer preparation, palmitic acid, nitroblue tetrazolium (NBT), diphenylene iodonium (DPI) and bysindoylmaleimide (GF109203X) were obtained from Sigma-Aldrich Chemical (St Louis, MO, USA), or Sigma (Dublin, Ireland). Hydroethidine (HEt) was obtained from Molecular Probes (Eugene, OR, USA). Protease inhibitors and EDTA were supplied by Pierce (Rockford, IL, USA). Culture media, fetal bovine serum, OPTI-MEM medium, oligofectamine, plasticware, trizol, random pd $(\mathrm{N})_{6}$ primers, DNase I, SuperScript II RNase H-Reverse Transcriptase II, Taq DNA polymerase and dNTPs were obtained from Invitrogen Life Technologies (Paisley, Scotland). Cytokines were obtained from R\&D Systems (Abingdon, UK). The $\mathrm{p} 47^{\text {phox }}$ rabbit antibodies were obtained from Santa Cruz Biotechnology (Santa Cruz, CA, USA). All procedures were carried out according to the various manufacturers' instructions. Palmitic acid was initially dissolved in ethanol, the final concentration of which did not exceed $0.05 \%$. 
Animals

Female Wistar albino rats weighing 150-200 g (45-60 days old) were obtained from the Institute of Biomedical Sciences, University of Sao Paulo, Sao Paulo, Brazil. The animals were kept in groups of five at $23^{\circ} \mathrm{C}$ in a room with a $12 \mathrm{~h}$ light-dark cycle (lights on at 07.00 hours) and free access to food and water. Ethics approval was granted for this study by the Animal Experimental Committee of the Institute of Biomedical Sciences, University of Sao Paulo.

Rat pancreatic islet isolation

Islets of Langerhans were isolated from rats by pancreas digestion with collagenase as previously described [18]. Islet apoptosis (assessed by DNA fragmentation) was not altered in any of the conditions described at any point up to $24 \mathrm{~h}$.

Superoxide determination: nitroblue tetrazolium and hydroethidine assays

Total superoxide generation was detected by NBT assay [19]. Superoxide is rapidly generated on activation of NADPH oxidase and has a short half-life. However, superoxide can reduce NBT to a relatively stable product detectable at $560 \mathrm{~nm}$. Previous studies have demonstrated that islet ROS-dependent NBT reduction was robust and was sustained for a 120-minute period following initiation [9]. The assay was performed by incubating 200 islets in $250 \mu \mathrm{l}$ Krebs-Henseleit buffer, with $0.2 \%$ NBT. The samples were incubated for 60 minutes or $24 \mathrm{~h}\left(37^{\circ} \mathrm{C}\right.$ and $5 \% \mathrm{CO}_{2}$ ) in the presence of glucose, $0.1 \mathrm{mmol} / 1$ palmitate, $10 \mu \mathrm{mol} / 1 \mathrm{DPI}$, an NADPH oxidase inhibitor [20, 21], or $500 \mathrm{nmol} / \mathrm{l}$ GF109203X, a PKC-specific inhibitor [22], or $5 \mathrm{ng} / \mathrm{ml} \mathrm{IL-1} \beta$ where indicated. The cells were centrifuged $\left(3,200 \mathrm{~g}\right.$ for $2 \mathrm{~min}$ at $\left.4^{\circ} \mathrm{C}\right)$ and the supernatant fraction removed. Formazan was dissolved in $100 \mu \mathrm{l} 50 \%$ acetic acid by sonication ( 3 pulses of 6 seconds, Vibra Cell; Sonics \& Materials, Newtown, CT, USA). Absorbance was determined at $560 \mathrm{~nm}$ in a microtitre plate reader (Spectramax Plus; Molecular Devices, Sunnyvale, CA, USA). Intracellular superoxide generation was also determined by oxidation of HEt to ethidium [23]. Islets were incubated at $37^{\circ} \mathrm{C}$ for $60 \mathrm{~min}$ or $24 \mathrm{~h}$ in $500 \mu \mathrm{Krebs}-$ Henseleit buffer in the presence of glucose $(2.8,5.6$ and $16.7 \mathrm{mmol} / \mathrm{l}$ ) with or without $10 \mu \mathrm{mol} / 1 \mathrm{DPI}$, or in the presence of $5.6 \mathrm{mmol} / 1$ glucose plus $0.1 \mathrm{mmol} / 1$ palmitate, or in the presence of $5.6 \mathrm{mmol} / \mathrm{l}$ glucose plus $5 \mathrm{ng} / \mathrm{ml}$ IL-1 $\beta$ with or without $10 \mu \mathrm{mol} / 1 \mathrm{DPI}$, as indicated. Islets were loaded with $100 \mu \mathrm{mol} / \mathrm{l} \mathrm{HEt}$ over $20 \mathrm{~min}$ at room temperature. Incubation medium was replaced and the islets loaded with HEt were washed with Krebs-Henseleit buffer without glucose and transferred to 96-well plates (containing $100 \mu \mathrm{l} \mathrm{Krebs-Henseleit} \mathrm{buffer} \mathrm{without} \mathrm{glu-}$ cose). Islets were visualised in a confocal microscope (Carl Zeiss, Morris Plains, NJ, USA). In these experiments, ethidium fluorescence was excited at $547 \mathrm{~nm}(3 \mu \mathrm{m}$ laser scanning confocal sections were analysed).

Phosphorthioate-modified oligonucleotides

Antisense phosphorthioate oligonucleotide target to $\mathrm{p} 47^{\text {phox }}$ (5'-CTTCATTCGCCACATCGC-3') and a control oligonucleotide containing the same bases but in random order (5'-TTTTCCCCCAGGCCCAAT-3') were designed according to the $\mathrm{p} 47^{\text {phox }}$ mRNA rat sequence (Genbank accession no. AY029167) and were produced by Integrated DNA Technologies (Coralville, IA, USA). The efficiency of antisense oligonucleotides blocking of $\mathrm{p} 47^{\text {phox }}$ protein production was evaluated by immunoblotting total protein extracts of isolated pancreatic islets using a specific anti-p $47^{\text {phox }}$ antibody.

Oligonucleotide transfection in cultured islets

and superoxide determination (hydroethidine assay)

Groups of 400 freshly isolated islets were pre-incubated for $4 \mathrm{~h}$ at $37^{\circ} \mathrm{C}$ in OPTI-MEM medium plus oligofectamine with $10 \mathrm{mmol} / 1$ glucose and in the absence or presence of either $20 \mu \mathrm{mol} / 1$ scrambled or $20 \mu \mathrm{mol} / 1$ antisense $\mathrm{p} 47^{\text {phox }}$ oligonucleotide. After $4 \mathrm{~h}$ of transfection, $9 \mathrm{ml}$ of RPMI 1640 medium with $10 \mathrm{mmol} / \mathrm{l}$ glucose and $10 \%$ fetal calf serum were added to the medium and islets were then incubated for $20 \mathrm{~h}$ at $37^{\circ} \mathrm{C}$. Thereafter, the RPMI-1640 medium was replaced by Krebs-Henseleit containing $5.6 \mathrm{mmol} / \mathrm{l}$ glucose and the islets were incubated for $30 \mathrm{~min}$. Afterwards, islets were loaded with HEt and incubated for $20 \mathrm{~min}$ at room temperature. The incubation medium was replaced and islets loaded with HEt were washed with Krebs-Henseleit buffer without glucose and transferred to 96-well plates. Islets were visualised using a confocal microscope (Carl Zeiss).

Western blotting for $\mathrm{p} 47^{\text {phox }}$

Groups of 300 islets were incubated in Krebs-Henseleit buffer containing 5.6, 11.1 and $16.7 \mathrm{mmol} / \mathrm{l}$ glucose or $0.1 \mathrm{mmol} / 1$ palmitate (with $5.6 \mathrm{mmol} / 1$ glucose) for $60 \mathrm{~min}$ at $37^{\circ} \mathrm{C}$. After incubation, protein from islets was extracted and diluted (1:5) in a 2-mercaptoethanol Lammeli buffer. For protein samples isolated from BRIN BD11 cells western blot analysis was carried out using $25 \mu \mathrm{g}$ or $30 \mu \mathrm{g}$ of cytoplasmic extracts (isolated using RIPA buffer as described below). The $25 \mu \mathrm{g}$ or $30 \mu \mathrm{g}$ of protein was boiled in an equal volume of $2 \times$ electrophoresis sample buffer. Equal amounts of protein were subjected to SDS- 
PAGE in a Bio-Rad miniature slab gel apparatus and electrophoretically transferred on to a nitrocellulose sheet, blocked in 5\% BSA and incubated overnight with purified polyclonal rabbit anti-p4 $7^{\text {phox }}$ antibody. The antibodies were used at dilutions of between 1:200 and 1:10,000 (depending on cell type). The blots were washed and probed with horseradish peroxidase (Santa Cruz Biotechnology). For BRIN-BD11 cells the SuperSignal west pico chemiluminescent substrate (Pierce, Rockford, IL, USA) was used to detect the signal. The working solution was prepared by mixing $3.5 \mathrm{ml}$ of the stable peroxide solution with $3.5 \mathrm{ml}$ of the luminol/enhancer solution. Glucose, palmitic acid or IL-1 $\beta$ at the concentrations used in this study did not alter production of a beta cell housekeeping

a

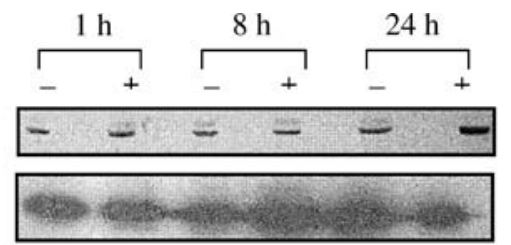

$\mathrm{p} 47^{\text {phox }}$

GAPDH
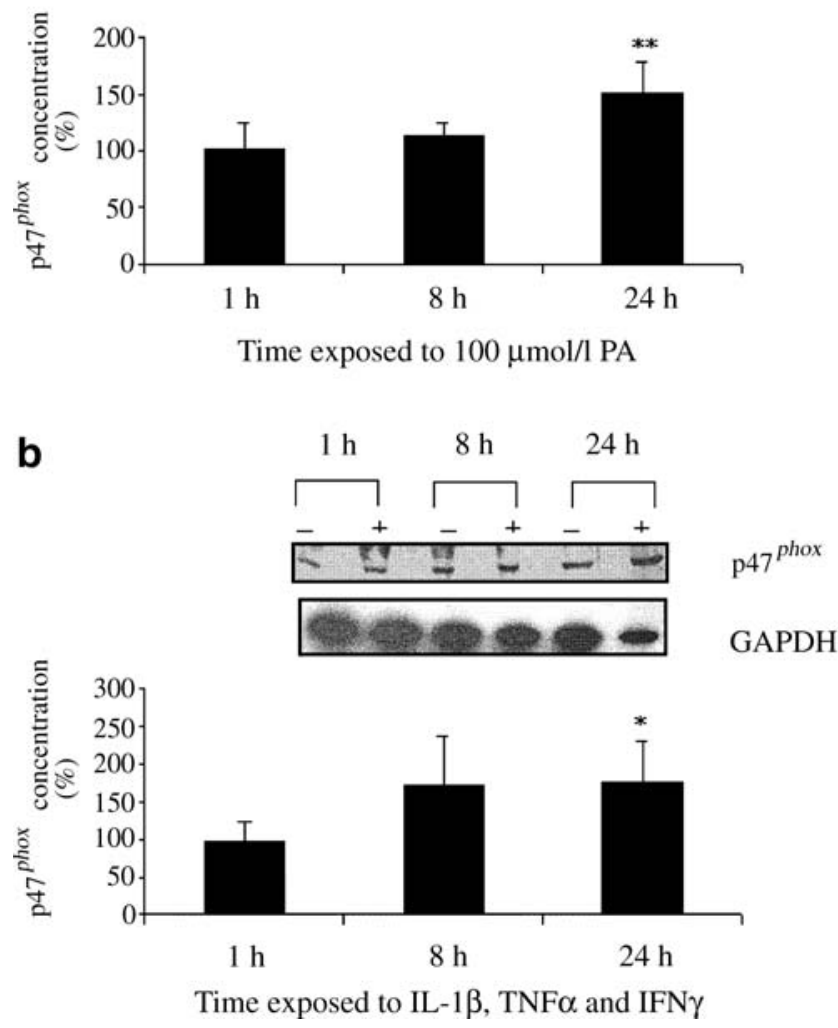

Fig. 1 Effect of palmitic acid or a pro-inflammatory cytokine mix on the production of the NADPH oxidase component $\mathrm{p} 47^{\text {phox }}$ in clonal beta cells. Western blotting analysis (a) of $\mathrm{p} 47^{\text {phox }}$ from protein isolated from BRIN-BD11 cells cultured for 1,8 or $24 \mathrm{~h}$ in the absence (control) or presence of either $100 \mu \mathrm{mol} / 1$ palmitic acid $(P A)$, or (b) a pro-inflammatory cytokine mix (TNF- $\alpha$ [1.9 ng/ml], IL-1 $\beta$ $[2.5 \mathrm{ng} / \mathrm{ml}]$ and IFN- $\gamma[125 \mathrm{ng} / \mathrm{ml}])$. Western blotting was performed using rabbit anti-p $47^{\text {phox }}$ or anti-GAPDH polyclonal antibodies. Similar results were obtained in three to six independent experiments. ${ }^{*} p<0.05,{ }^{* *} p<0.01$ compared with control cells cultured in the absence of fatty acid or cytokines protein glyceraldehyde-3-phosphate dehydrogenase (GAPDH) (Fig. 1) or an islet housekeeping protein, fibronectin (Figs 2, 3, 4 and 5). Islet cell viability was not altered by any of the conditions described over $24 \mathrm{~h}$ (results not shown).

Culture and treatment of BRIN-BD11 cells

Clonal insulin-secreting BRIN-BD11 cells were maintained in RPMI-1640 tissue culture medium with $10 \%(\mathrm{v} / \mathrm{v})$ fetal calf serum, $0.1 \%$ antibiotics $(100 \mathrm{U} / \mathrm{ml}$ penicillin, $0.1 \mathrm{mg} / \mathrm{ml}$ streptomycin) and $11.1 \mathrm{mmol} / \mathrm{l} \mathrm{D}$-glucose, $\mathrm{pH} 7.4$, at $37^{\circ} \mathrm{C}$ in a humidified atmosphere of $5 \% \mathrm{CO}_{2}$ and $95 \%$ air using an incubator (Forma Scientific Biosciences, Dublin, Ireland). For western blot analysis, the cells were seeded at $1.5 \times 10^{6}$ cells per well in $5 \mathrm{ml}$ medium in a six-well plate. The cells were allowed to adhere overnight and then incubated as above but in the presence or absence of different concentrations of a pro-inflammatory cytokine mix (TNF- $\alpha$ $[1.9 \mathrm{ng} / \mathrm{ml}], \mathrm{IL}-1 \beta[2.5 \mathrm{ng} / \mathrm{ml}]$ and IFN- $\gamma[125 \mathrm{ng} / \mathrm{ml}])$ or

a
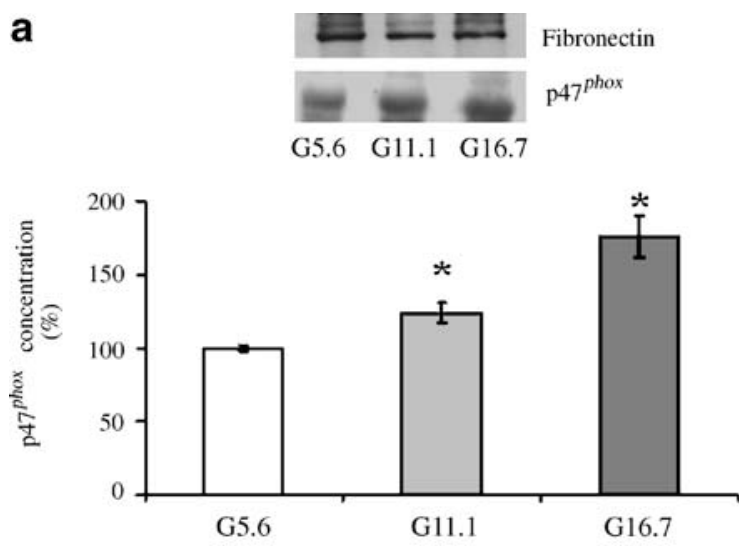

b
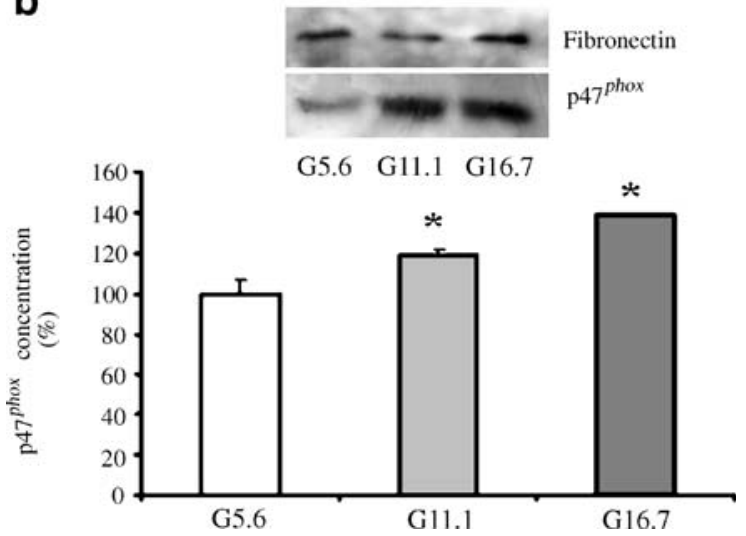

Fig. 2 Effect of glucose on production of the NADPH oxidase components $\mathrm{p} 47^{\text {phox }}$ in rat islets. Western blotting analysis of $\mathrm{p} 47^{\text {phox }}$ after $1 \mathrm{~h} \mathrm{(a)} \mathrm{and} 24 \mathrm{~h} \mathrm{(b)} \mathrm{from} \mathrm{isolated} \mathrm{rat} \mathrm{pancreatic} \mathrm{islets} \mathrm{incubated} \mathrm{in}$ the presence of 5.6 (G5.6), 11.1 (G11.1) and 16.7 (G16.7) mmol/1 glucose for $1 \mathrm{~h}$ or $24 \mathrm{~h}$, respectively. Western blotting was performed using rabbit anti-p4 $7^{\text {phox }}$ or anti-fibronectin polyclonal antibodies. Similar results were obtained in three independent experiments. ${ }^{*} p<0.05$, compared with $5.6 \mathrm{mmol} / 1$ glucose 
a
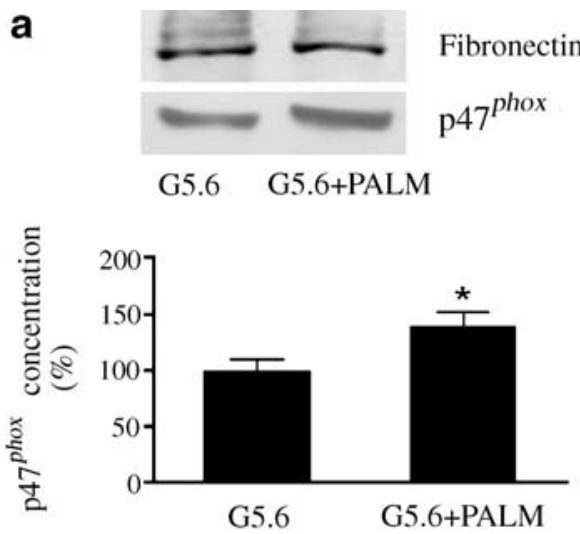

b
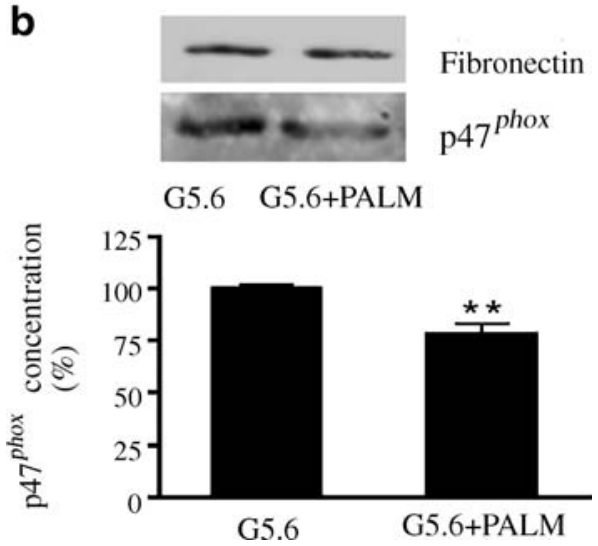

Fig. 3 Effect of palmitate on production of the NADPH oxidase component $\mathrm{p} 47^{\text {phox }}$ in rat islets. Western blotting analysis of $\mathrm{p} 47^{\text {phox }}$ from isolated pancreatic islets incubated in the presence of $5.6 \mathrm{mmol} / \mathrm{l}$ glucose $(G 5.6)$ or $5.6 \mathrm{mmol} / 1$ glucose plus $0.1 \mathrm{mmol} / 1$ palmitate $(G 5.6+P A L M)$ after $1 \mathrm{~h}$ (a) or $24 \mathrm{~h}(\mathbf{b})$. Western blotting was performed using rabbit anti-p $47^{\text {phox }}$ or anti-fibronectin polyclonal antibody. Similar results were obtained in three independent experiments. ${ }^{*} p<0.05$, compared with $5.6 \mathrm{mmol} / 1$ glucose. ${ }^{* *} p<0.01$ compared with $5.6 \mathrm{mmol} / \mathrm{l}$ glucose

the presence or absence of $100 \mu \mathrm{mol} / \mathrm{l}$ palmitic acid for 1,8 or $24 \mathrm{~h}$. BRIN BD11 cell viability (as assessed by the tetrazolium salt WST-1, an indicator of mitochondrial integrity) was reduced by approximately $10 \%$, in the presence of palmitic acid, but apoptosis (as assessed by loss of nuclear integrity) was increased from $5 \%$ to $25 \%$ in the presence of the pro-inflammatory cytokine cocktail after $24 \mathrm{~h}$ [24].

Preparation of protein extracts from BRIN-BD11 cells

BRIN-BD11 insulin-secreting cells were lysed using RIPA lysis buffer (supplied at $10 \times$ concentration; MSC, Dublin, Ireland) containing protease inhibitors. $150 \mu \mathrm{l}$ of $1 \times$ RIPA lysis buffer was added to the cells. Cell lysates were transferred to fresh ice-cold Eppendorf tubes and were then placed on a shaker at $4^{\circ} \mathrm{C}$ for $15 \mathrm{~min}$. The cells were then centrifuged at $14,000 \mathrm{~g}$ for $15 \mathrm{~min}$ at $4^{\circ} \mathrm{C}$. The supernatant fraction was placed in a fresh tube and stored at $-20^{\circ} \mathrm{C}$. a
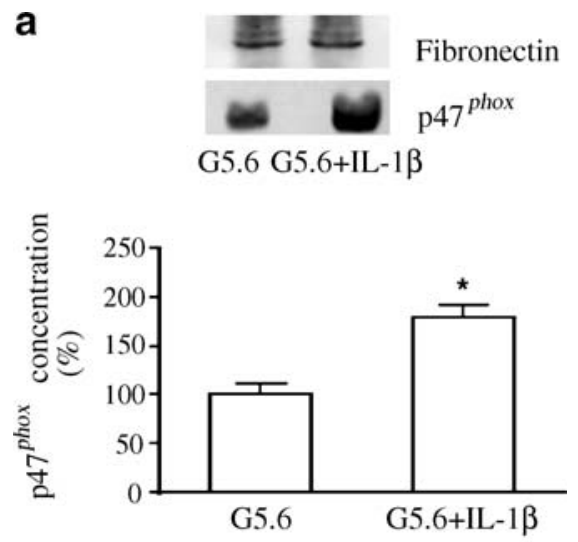

b
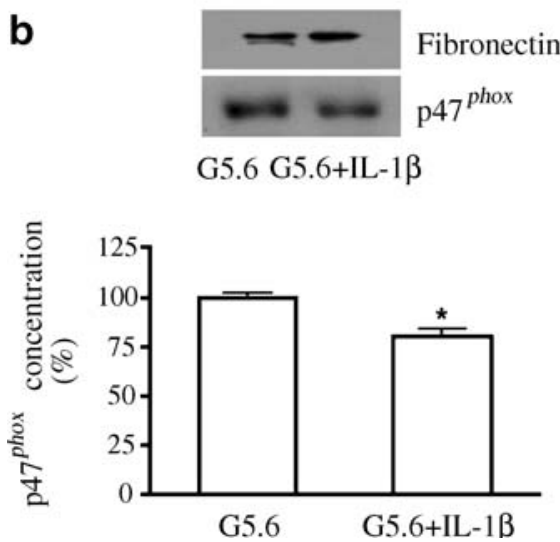

Fig. 4 Effect of IL-1 $\beta$ on production of the NADPH oxidase components $\mathrm{p} 47^{\text {phox }}$ in rat islets. Western blotting analysis of $\mathrm{p} 47^{\text {phox }}$ from isolated pancreatic islets incubated in the presence of $5.6 \mathrm{mmol} / 1$ glucose $(G 5.6)$ or $5.6 \mathrm{mmol} / 1$ glucose plus $5 \mathrm{ng} / \mathrm{ml} \mathrm{IL-1} \beta(G 5.6+I L$ $1 \beta)$ after $1 \mathrm{~h}(\mathbf{a})$ or $24 \mathrm{~h}(\mathbf{b})$. Western blotting was performed using rabbit anti-p4 $7^{\text {hox }}$ or anti-fibronectin polyclonal antibody. Similar results were obtained in three independent experiments. ${ }^{*} p<0.05$, compared with $5.6 \mathrm{mmol} / \mathrm{l}$ glucose

\section{Statistical analysis}

Results are presented as mean \pm SEM. ANOVA was employed to verify significance where appropriate, with confidence levels set at $p<0.05$. Statistical analyses were also performed using the unpaired Student's $t$ test where appropriate. $P<0.05$ was considered to be statistically significant.

\section{Results}

Effect of palmitate or a pro-inflammatory cytokine cocktail on BRIN-BD11 $\mathrm{p} 47^{\text {phox }}$ protein production

BRIN BD11 insulin-secreting cells were incubated in the presence of $0.1 \mathrm{mmol} / 1$ palmitic acid or of the proinflammatory cytokine mix (IL-1 $\beta$, TNF- $\alpha$ and IFN- $\gamma$ ) at non-toxic levels (TNF- $\alpha$ [1.9 ng/ml], IL-1 $\beta[2.5 \mathrm{ng} / \mathrm{ml}]$ and IFN- $\gamma[125 \mathrm{ng} / \mathrm{ml}]) . \mathrm{p} 47^{\text {phox }}$ protein levels were subsequently determined by western blotting techniques after 1 , 


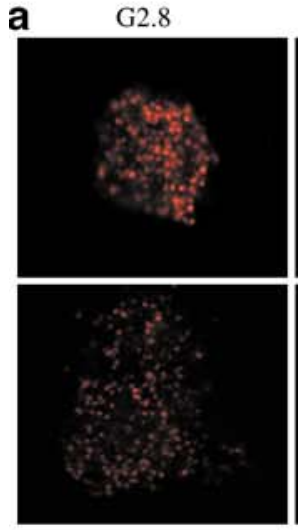

G2.8+DPI

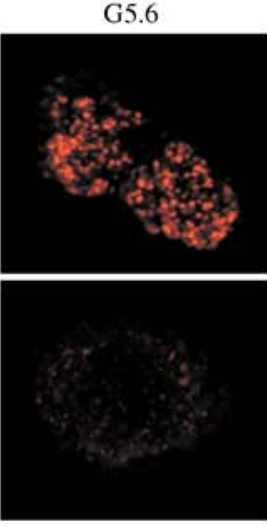

G5.6+DPI

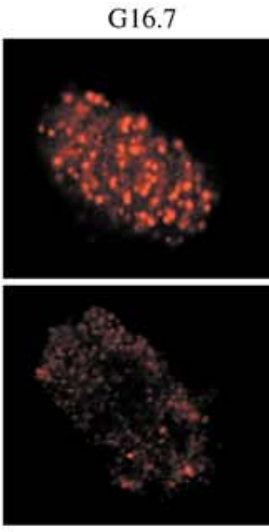

G16.7+DPI

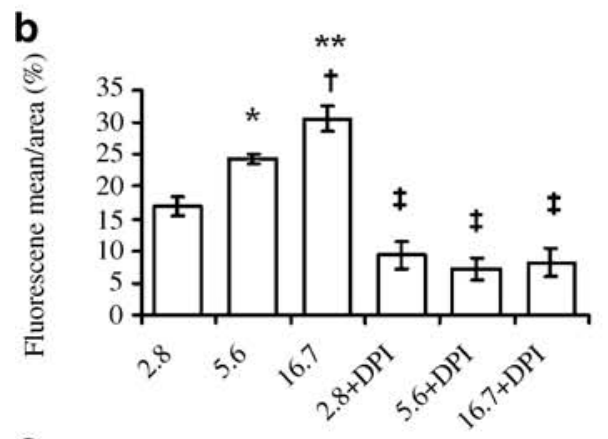

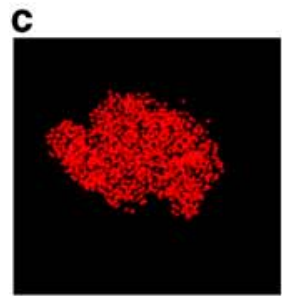

Control

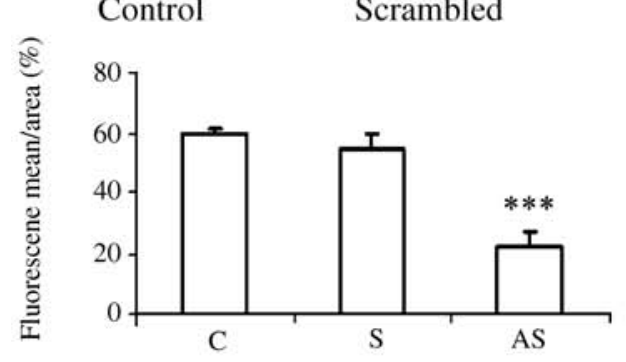

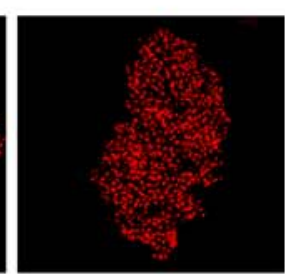

Antisense

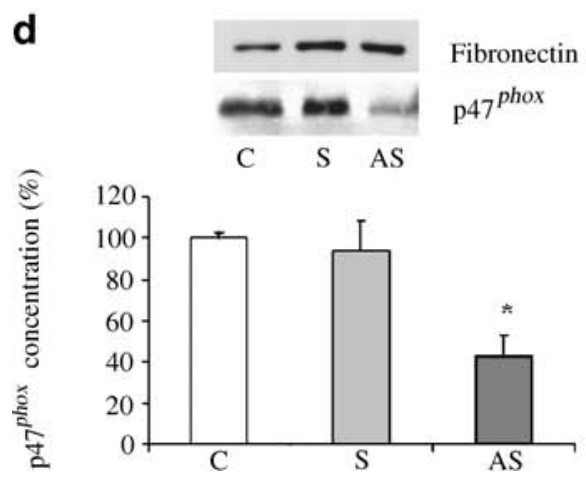

Fig. 5 Effect of glucose on ROS production in isolated pancreatic islets. The production of ROS by isolated rat pancreatic islets was determined using a hydroethidine oxidation assay. The fluorescence intensity of islets was analysed using Zeiss confocal microscopy (a). Fluorescence increased as a function of glucose concentration. Groups of 20 islets were incubated in the presence of $2.8(G 2.8), 5.6(G 5.6)$ or $16.7($ G16.7) $\mathrm{mmol} / \mathrm{l}$ of glucose and in the absence or presence of $10 \mu \mathrm{mol} / \mathrm{l}$ of DPI $(n=3)$. b As above (a) but the results are expressed as means \pm SE from pools of 20 islets. ${ }^{*} p<0.05,{ }^{* *} p<0.01$, compared with $2.8 \mathrm{mmol} / 1$ glucose; $\dagger p<0.05$, compared with $5.6 \mathrm{mmol} / 1$ glucose; $\ddagger p<0.05$, compared with respective glucose concentration. c In addition, the islets were incubated in $10 \mathrm{mmol} / 1$ glucose only $(C)$ or in the presence of a control random order oligonucleotide, 'scrambled' $(S)$, or antisense $(A S) \mathrm{p} 47^{p h o x}$, and the production of superoxide was determined as described above, after a 4-h transfection period followed by $20 \mathrm{~h}$ incubation. The results are expressed as means \pm SE from pools of 20 islets each. ${ }^{* *} p<0.001$, compared with the control. The $\mathrm{p} 47^{p h o x}$ or fibronectin production was also determined by western blotting (d) following transfection with control or antisense oligonucleotide and $20 \mathrm{~h}$ of incubation. The results are expressed as means \pm SE from pools of 20 islets each. ${ }^{*} p<0.05$, compared with the control

8 and $24 \mathrm{~h}$ and found to be significantly increased after incubation in the presence of palmitic acid or the proinflammatory cytokine cocktail after $24 \mathrm{~h}$ (1.5-fold and 1.75-fold, respectively) (Fig. 1a,b). Production of the housekeeping protein, GAPDH was not altered in any experimental condition.

Effect of glucose on production of rat islet $\mathrm{p} 47^{\text {phox }}$

The effect of glucose on production of the NADPH oxidase component $\mathrm{p} 47^{\text {phox }}$ was examined in isolated rat islets by western blotting after 1 and $24 \mathrm{~h}$. Incubation in the presence of $16.7 \mathrm{mmol} / \mathrm{l}$ glucose resulted in an increase in the production of $\mathrm{p} 47^{\text {phox }}$ by 1.7 -fold after $1 \mathrm{~h}$ and 1.4 -fold after $24 \mathrm{~h}$, as compared with production at $5.6 \mathrm{mmol} / \mathrm{l}$ glucose (Fig. 2a,b). After 1 and $24 \mathrm{~h}$ of incubation glucose increased $\mathrm{p} 47^{\text {phox }}$ production in a dose-dependent manner $(5.6<11.1<16.7 \mathrm{mmol} / \mathrm{l}$ glucose) (Fig. 2a,b).

Effect of palmitate or IL-1 $\beta$ on $\mathrm{p} 47^{\text {phox }}$ production

The effect of palmitate on $\mathrm{p} 47^{p h o x}$ production in rat islets was investigated by western blotting. Pancreatic islets were incubated for 1 or $24 \mathrm{~h}$ in the presence of $5.6 \mathrm{mmol} / 1$ glucose only or $5.6 \mathrm{mmol} / 1$ glucose plus $0.1 \mathrm{mmol} / \mathrm{l}$ palmitate. The production of $\mathrm{p} 47^{\text {phox }}$ in islets incubated in presence of palmitate plus glucose was increased by 1.4-fold compared with the effect of glucose only after $1 \mathrm{~h}$ (Fig. 3a), but was reduced by approximately $23 \%$ compared with control (5.6 mmol/l) after $24 \mathrm{~h}$ (Fig. 3b).

The effect of the pro-inflammatory cytokine IL- $1 \beta$ on islet $\mathrm{p} 47^{\text {phox }}$ production was investigated by western 
blotting. Pancreatic islets were incubated for $1 \mathrm{~h}$ in the presence of $5.6 \mathrm{mmol} / \mathrm{l}$ glucose only or of $5.6 \mathrm{mmol} / \mathrm{l}$ glucose plus $5 \mathrm{ng} / \mathrm{ml} \mathrm{IL-1} \beta$. After $1 \mathrm{~h}$, the production of $\mathrm{p} 47^{\text {phox }}$ in islets incubated in presence of IL- $1 \beta$ plus glucose was increased (1.8-fold) compared with the effect of glucose only (Fig. 4a); after $24 \mathrm{~h}$ production was reduced by approximately $21 \%$ (Fig. 4b).

Effect of glucose on ROS production in islet cells and pharmacological/molecular inhibition

Intracellular ROS production by incubated islets (as determined by HEt assay) was increased on incubation of islets in 5.6 or $16.7 \mathrm{mmol} / 1$ when compared with a basal concentration of $2.8 \mathrm{mmol} / \mathrm{l}$ glucose (Fig. 5a,b). DPI, an inhibitor of NADPH oxidase, completely abolished glucose induced ROS production (Fig. 5a,b).

ROS production was inhibited by a specific anti-p47 $7^{\text {phox }}$ oligonucleotide in islets cultured for $24 \mathrm{~h}$ in the presence of $10 \mathrm{mmol} / \mathrm{l}$ glucose (Fig. 5c). The inhibitory effect of the oligonucleotide on $\mathrm{p} 47^{\text {phox }}$ production was confirmed by western blotting. p $47^{\text {phox }}$ protein was produced at $40 \%$ of the level achieved in the absence of the oligonucleotide after $24 \mathrm{~h}$ (Fig. 5d), an effect not achieved with a control oligonucleotide containing the same bases but in random order.

Effect of palmitate on ROS production in islet cells

Islets incubated in the presence of glucose $(5.6 \mathrm{mmol} / \mathrm{l})$ produced ROS at levels sufficient to be detected by the NBT reduction assay (which assesses both intracellular and extracellular ROS) after $1 \mathrm{~h}$. Addition of $0.1 \mathrm{mmol} / \mathrm{l}$ palmitate to incubation media containing $5.6 \mathrm{mmol} / \mathrm{l}$ glucose significantly increased the NBT reduction after $1 \mathrm{~h}$ (1.68-fold, Fig. 6a). Additionally islets were incubated for $1 \mathrm{~h}$ in $5.6 \mathrm{mmol} / 1$ glucose plus $0.1 \mathrm{mmol} / 1$ palmitate in the presence of DPI, which resulted in partial attenuation of ROS production (Fig. 6a). PKC is the main cellular regulator of NADPH oxidase activity (16). The effect of GF109203X (a PKC inhibitor) was examined to ascertain the role of PKC on NADPH oxidase activation. GF109203X significantly attenuated the NBT reduction induced by palmitate plus glucose (Fig. 6b).

Palmitate plus glucose also raised intracellular ROS production after $1 \mathrm{~h}$ (by 2.5 -fold), as evaluated by the $\mathrm{HEt}$ assay, compared with $5.6 \mathrm{mmol} / \mathrm{l}$ glucose only, an effect that was partially but significantly attenuated by DPI (Fig. 7a).

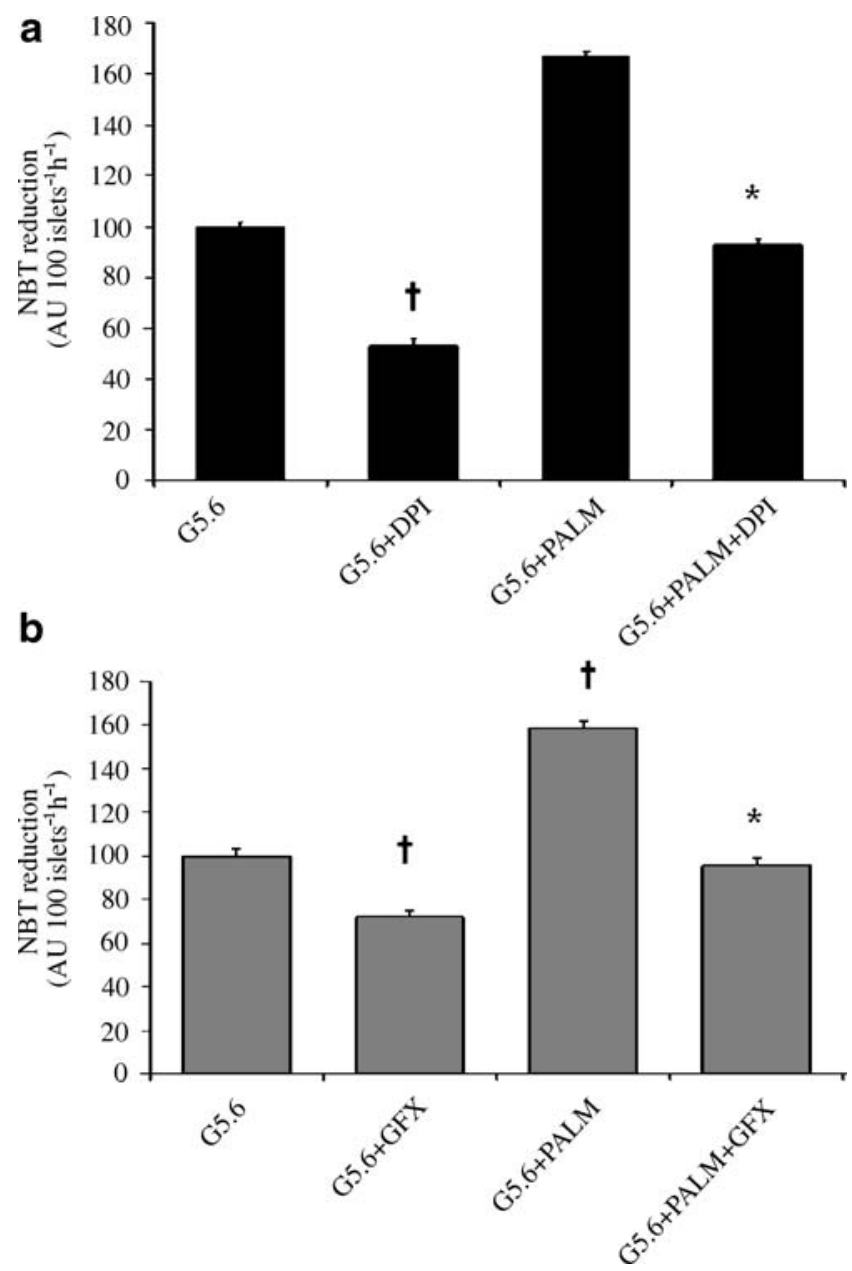

Fig. 6 Effect of palmitate and NADPH oxidase or PKC inhibitors on ROS production in rat islets. The production of superoxide by isolated rat pancreatic islets incubated in glucose (G5.6) or glucose plus palmitate $(P A L M)$ in the presence or absence of $10 \mu \mathrm{mol} / 1 \mathrm{DPI}$ (a) or (b) $500 \mathrm{nmol} / 1$ GF109203X (GFX) was determined by NBT reduction assay. The islets were incubated for $60 \mathrm{~min}$ in Krebs-Henseleit buffer containing $0.2 \% \mathrm{NBT}$ in the absence (ethanol $0.5 \%$ ) or presence of $5.6 \mathrm{mmol} / 1$ glucose or of $5.6 \mathrm{mmol} / 1$ glucose plus either $0.1 \mathrm{mmol} / \mathrm{l}$ palmitate $(n=3)$ or DPI or palmitate plus DPI, or GF109203X or palmitate plus GF109203X. $A U$, arbitrary units. The results are expressed as means $\pm \mathrm{SE}$ from pools of 100 islets each. $\dagger p<0.05$, compared with $5.6 \mathrm{mmol} / 1$ glucose; $* p<0.05$, compared with $5.6 \mathrm{mmol} / 1$ glucose plus $0.1 \mathrm{mmol} / 1$ palmitate

Effect of IL-1 $\beta$ on ROS production in islet cells

Islets incubated for $1 \mathrm{~h}$ in the presence of $5.6 \mathrm{mmol} / 1$ glucose plus $5 \mathrm{ng} / \mathrm{ml}$ IL- $1 \beta$ produced intracellular ROS at significantly higher levels compared with incubation in $5.6 \mathrm{mmol} / 1$ glucose only, as assessed by the hydroethidine assay. When islets were incubated for $1 \mathrm{~h}$ in the presence of $5.6 \mathrm{mmol} / 1$ glucose plus $5 \mathrm{ng} / \mathrm{ml} \mathrm{IL}-1 \beta$ and in the presence 


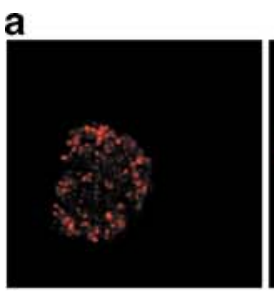

G5.6

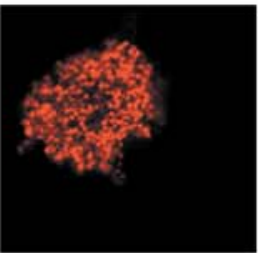

G5.6+Palm

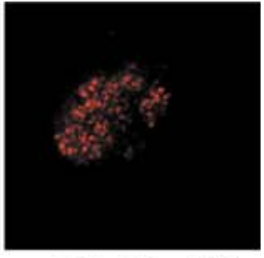

G5.6+Palm+DPI

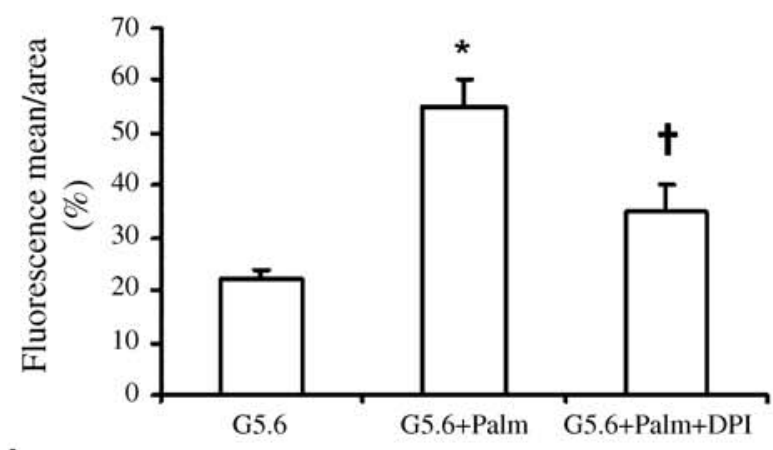

b

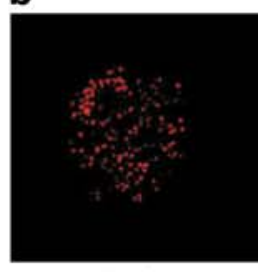

G5.6

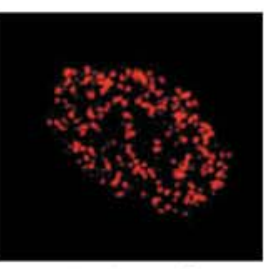

G5.6+IL-1 $\beta$

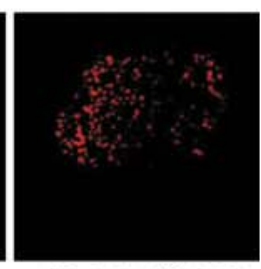

G5.6+IL-1 $\beta+\mathrm{DPI}$

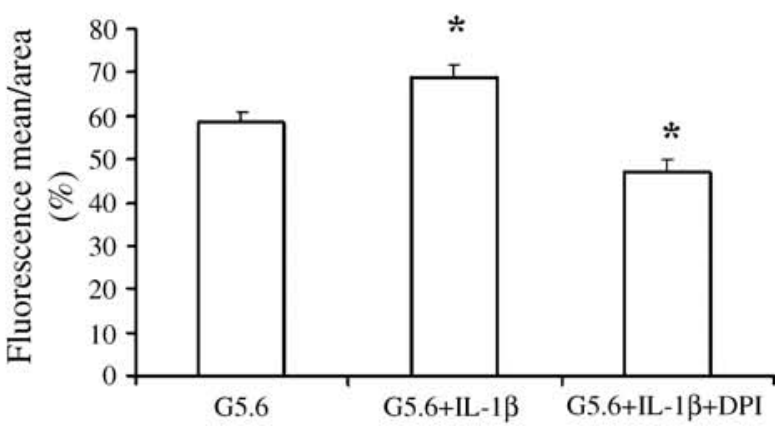

C

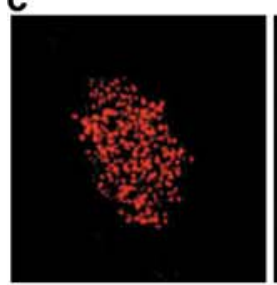

G5.6

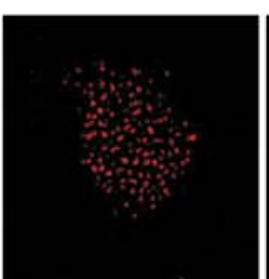

G5.6+Palm

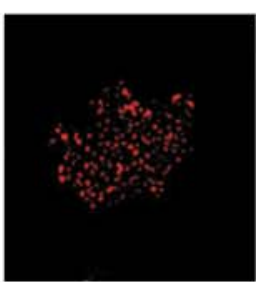

G5.6+IL-1 $\beta$

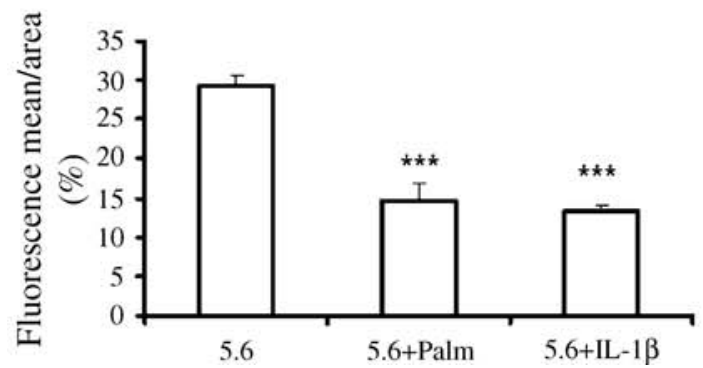

Fig. 7 Effect of palmitate or IL-1 $\beta$ on ROS production assessed by ethidium fluorescence in isolated pancreatic islets. The production of ROS by isolated rat pancreatic islets was determined using a hydroethidine oxidation assay. The fluorescence intensity of islets was analysed by Zeiss confocal microscopy. Groups of 20 islets were incubated for $1 \mathrm{~h}$ in the presence of $5.6 \mathrm{mmol} / 1$ glucose (G5.6), $5.6 \mathrm{mmol} / 1$ glucose plus $0.1 \mathrm{mmol} / \mathrm{l}$ palmitate $(P A L M), 5.6 \mathrm{mmol} / 1$ glucose plus $5 \mathrm{ng} / \mathrm{ml} \mathrm{IL-1} \beta$, and for the latter two also in the absence or presence of $10 \mu \mathrm{mol} / 1$ of DPI $(\mathbf{a}, \mathbf{b})(n=3)$. $\mathbf{c}$ Islets were incubated as above (a, b), but for $24 \mathrm{~h}(n=3)$. The results are expressed as means \pm SE. ${ }^{*} p<0.05$, compared with $5.6 \mathrm{mmol} / 1$ glucose; ${ }^{* * *} p<0.001$, as compared with $5.6 \mathrm{mmol} / 1$ glucose; $\uparrow p<0.05$, as compared with $5.6 \mathrm{mmol} / 1$ glucose and $0.1 \mathrm{mmol} / \mathrm{l}$ palmitate

of DPI, a partial but significant attenuation of ROS production was observed (Fig. 7b).

Islets incubated for $24 \mathrm{~h}$ in the presence of palmitate or IL-1 $\beta$ plus glucose $(5.6 \mathrm{mmol} / \mathrm{l})$ produced intracellular ROS at significantly lower levels compared with incubation in $5.6 \mathrm{mmol} / 1$ glucose only, as assessed by the HEt assay. (Fig. 7c).

\section{Discussion}

We recently demonstrated the production of a phagocytelike NADPH oxidase in the beta cells of rat pancreatic islets [9]. Expression of cytosolic and membrane NADPH oxidase components was demonstrated by RT-PCR and western blotting. Remarkably the level of ROS production in beta cells was shown to be similar although slightly lower than for rat neutrophils. We now demonstrate that $\mathrm{p} 47^{\text {phox }}$, a key NADPH oxidase component, is also produced in a clonal rat pancreatic insulin-secreting cell line, BRIN BD11, that is responsive to glucose and amino acids. Thus NADPH oxidase production occurs in a pure homogenous beta cell population. Protein production of $\mathrm{p} 47^{\text {phox }}$ was significantly increased in the presence of palmitic acid or a pro-inflammatory cytokine cocktail after $24 \mathrm{~h}$ in the cell line. In rat islets, by contrast, production of $\mathrm{p} 47^{\text {phox }}$ protein was significantly increased in the presence of glucose, palmitic acid or the pro-inflammatory cytokine IL-1 $\beta$ after $1 \mathrm{~h}$, but was reduced after $24 \mathrm{~h}$ in the presence of the latter two agents. We have reported here that, similarly to leucocytes, vascular cells and mesangial cells, glucose stimulated ROS production in islets mainly through NADPH oxidase activation (based on DPI and antisense oligonucleotide results). Indeed ROS production may be positively correlated with glucose-stimulated insulin secretion [25], although previously the source of beta cell ROS had been a matter of speculation. Recently it was reported [11] that glucose and sulfonylureas stimulated ROS production in a beta cell line, MIN6, through activation of NADPH oxidase. Pro-inflammatory cytokines are known to increase NADPH oxidase production and activity in the 
phagocytic cells of the immune system such as neutrophils and monocytes $[14,15]$. It is thus intriguing that components of the NADPH oxidase system are expressed in the pancreatic beta cell. From the evidence provided in this paper and others [9-11], it can be deduced that glucose rapidly increases production and activity of the NADPH oxidase system in the beta cell. It is possible that enhanced production of NADPH oxidase is more robust in vivo, where both glucose and palmitic acid concentrations may remain chronically elevated, and this may lead to elevated levels of apoptosis. Of related interest, arachidonic acid, which promoted insulin secretion and proliferation in the BRIN BD11 insulin-secreting cell line [26], did not increase $\mathrm{p} 47^{\text {phox }}$ production up to $24 \mathrm{~h}$ after exposure (results not shown).

IL-1 $\beta$ is known to induce apoptosis of islet cells by stimulating cytochrome $c$ release from the mitochondria with subsequent activation of downstream caspases [27]. Pro-inflammatory cytokine mixtures (especially IL-1 $\beta$, TNF- $\alpha$ and IFN- $\gamma$ ) are often required to induce death in rat beta cell lines, and appear to activate key caspases resulting in DNA fragmentation and induction of apoptosis. Cytokines also induce nitric oxide synthase production in beta cells, but nitric oxide production is not absolutely required for cytokine-induced beta cell death [26]. We have reported in this paper that IL- $1 \beta$ mediated an up-regulation of $\mathrm{p} 47^{p h o x}$ production and ROS production in islet cells, while a pro-inflammatory cytokine cocktail increased $\mathrm{p} 47^{\text {phox }}$ protein levels in the clonal beta cell line BRIN BD11. It is therefore possible that pro-inflammatory cytokines increase NADPH-oxidase-dependent ROS production in the beta cell, resulting in Jun N-terminal kinase activation, cytochrome $c$ release, caspase activation and thus apoptosis as recently described [28].

Reduction of $\mathrm{p} 47^{\text {phox }}$ production in rat islets after $24 \mathrm{~h}$ of exposure to sub-apoptotic levels of IL-1 $\beta$ may reflect activation of a cellular protective mechanism which in vivo would reduce levels of apoptosis. Indeed most beta cell lines are generally more resistant to apoptosis than their primary cell counterpart, and so enhanced $\mathrm{p} 47^{\text {phox }}$ production may be tolerated at $24 \mathrm{~h}$ in the BRIN BD11 cell line, as reported here. However, exposure to pro-inflammatory cytokines at higher levels will induce apoptosis by increasing nitric oxide synthesis and activating stress response pathways (including endoplasmic reticulum stress) and mitochondrial dysfunction.

The NADPH oxidase complex will use NADPH as a source of reducing equivalents and molecular oxygen to generate $\mathrm{O}_{2}^{-}$. The source of the NADPH is of critical importance to the beta cell, which has a relatively low pentose phosphate pathway activity [27]. Interestingly the beta cell contains malic enzyme, capable of converting malate to pyruvate with the concomitant production of
NADPH from $\mathrm{NADP}^{+}$[29]. The function of the generation of NADPH in the beta cell, although positively correlated with insulin secretion, has never been clarified. We would suggest that NADPH contributes to ROS generation via its role as substrate in the NADPH-oxidase-catalysed reduction of molecular oxygen. While the normal role of ROS in the beta cell must at present be a matter of speculation, it may be related to the regulation of redox-sensitive enzymes, signal transduction components or transcription factors, which can subsequently regulate secretion and insulin gene transcription. However, in conditions that are damaging and pathogenic to beta cells, such as the continuously high circulating levels of both glucose and palmitic acid known to occur in type 2 diabetes [30,31] or the sustained exposure to pro-inflammatory cytokines known to occur in type 1 diabetes, the upregulated production and activity of NADPH oxidase may result in excessive ROS production in the beta cell. This would subsequently impact on mitochondrial function, resulting in impaired ATP production and insulin secretion, and possibly contributing to an increase in apoptosis [32]. However, in vitro a prolonged period of incubation may result in a reduction in extracellular palmitic acid or cytokine levels (due to consumption or proteolysis, respectively), thus lowering the primary stimulus. In vivo, where fatty acid or cytokine levels can remain high over extended periods, beta cell ROS generation and its regulation in the context of mitochondrial dysfunction, endoplasmic reticulum stress and other apoptotic mechanisms may be a unifying biochemical mechanism that contributes to beta cell dysfunction and destruction in either type 1 or type 2 diabetes.

We also present evidence here that the glucose-dependent effect of palmitate on ROS production by islets is mediated via PKC activation, probably involving diacylglycerol production and subsequent stimulation of PKC activity (a mechanism reported for glucose-induced ROS production in mesangial cells [10]). Therefore glucose and palmitate together may augment de novo synthesis of diacylglycerol (palmitate rich), PKC activation and consequently NADPH oxidase activation in pancreatic islet cells. As PKC is involved in the amplifying ( $\mathrm{K}_{\mathrm{ATP}}$ channelindependent) mechanism controlling insulin secretion, the effect of palmitic acid would not be expected to involve alteration of ion-channel-dependent events that control insulin secretion.

ROS generation and its regulation may thus be used by a wide variety of cell types for different physiological purposes. Phagocytic cells may use ROS generation for bacterial damage and destruction, but protect themselves due to high levels of expression and activities of antioxidant enzyme systems including superoxide dismutase and catalase. Pancreatic beta cells may be particularly susceptible to ROS damage due to low levels of production 
of specific antioxidant enzymes including catalase [33, 34]. Beta cells may therefore be particularly susceptible to excessive ROS generation in the presence of additional stress, e.g. nitric oxide and mitochondrial dysfunction, therefore explaining their unique response to palmitic acid and pro-inflammatory cytokines resulting in dysfunction and destruction in either type 2 or type 1 diabetes.

Acknowledgements This study was supported by The State of São Paulo Research Foundation (FAPESP), Programme for Support for Centres of Excellence (PRONEX, Brazil), The National Council for Scientific and Technological Development (CNPq, Brazil), The Health Research Board of Ireland and Enterprise Ireland. We are grateful to A. da Silva Alves for the excellent technical assistance with the confocal microscope.

Duality of interest There is no duality of interest with regard to any of the authors of this paper.

\section{References}

1. Alcazar O, Qiu-yue Z, Gine E, Tamarit-Rodriguez J (1997) Stimulation of islet protein kinase $\mathrm{C}$ translocation by palmitate requires metabolism of the fatty acid. Diabetes 46:1153-1158

2. Haber EP, Procópio J, Carvalho CRO, Carpinelli AR, Newsholme P, Curi R (2006) New insights into fatty acid modulation of pancreatic beta cell function. Int Rev Cytol 248:1-41

3. Yaney GC, Korchak HM, Corkey BE (2000) Long-chain acyl CoA regulation of protein kinase $\mathrm{C}$ and fatty acid potentiation of glucose-stimulated insulin secretion in clonal beta-cells. Endocrinology 141:1989-1998

4. Quinn MT, Ammons MCB, DeLeo FR (2006) The expanding role of NADPH oxidases in health and disease: no longer just agents of death and destruction. Clin Sci 111:1-20

5. Sheppard FR, Kelher MR, Moore EE, McLaughlin NJ, Banerjee A, Silliman CC (2005) Structural organization of the neutrophil NADPH oxidase: phosphorylation and translocation during priming and activation. J Leukoc Biol 78:1025-1042

6. Dupuy C, Virion A, Ohayon R, Kaniewski J, Deme D, Pommier J (1991) Mechanism of hydrogen peroxide formation catalyzed by NADPH oxidase in thyroid plasma membrane. J Biol Chem 266:3739-3743

7. Bey EA, Xu B, Bhattacharjee A et al (2004) Protein kinase C delta is required for $\mathrm{p} 47$ phox phosphorylation and translocation in activated human monocytes. J Immunol 173:5730-5738

8. Fontayne A, Dang PM, Gougerot-Pocidalo MA, El-Benna J (2002) Phosphorylation of p47phox sites by PKC alpha, beta II, delta, and zeta: effect on binding to p22phox and on NADPH oxidase activation. Biochemistry 41:7743-7750

9. Oliveira HR, Verlengia R, Carvalho CR, Britto LR, Curi R, Carpinelli AR (2003) Pancreatic beta-cells express phagocyte-like NADPH oxidase. Diabetes 52:1457-1463

10. Hua H, Munk S, Goldberg H, Fantus G, Whiteside CI (2003) High glucose-suppressed endothelin-1 $\mathrm{Ca} 2+$ signaling via NADPH oxidase and diacylglycerol-sensitive protein kinase $\mathrm{C}$ isozymes in mesangial cells. J Biol Chem 278:33951-33962

11. Tsubouchi H, Inoguchi T, Inuo M et al (2005) Sulfonylurea as well as elevated glucose levels stimulate reactive oxygen species production in the pancreatic beta-cell line, MIN6 - a role of
NADPH oxidase in beta-cells. Biochem Biophys Res Commun 326:60-65

12. Carlsson C, Borg LA, Welsh N (1999) Sodium palmitate induces partial uncoupling and reactive oxygen species in rat pancreatic islets in vitro. Endocrinology 140:3422-3428

13. Brownlee M (2001) Biochemistry and molecular biology of diabetic complications. Nature 414:813-820

14. Brown GE, Stewart MQ, Bissonnette SA, Elia AE, Wilker E, Yaffe MB (2004) Distinct ligand-dependent roles for p38 MAPK in priming and activation of the neutrophil NADPH oxidase. J Biol Chem 279:27059-27068

15. Mazzi P, Donini M, Margotto D, Wientjes F, Dusi S (2004) IFNgamma induces gp91phox expression in human monocytes via protein kinase C-dependent phosphorylation of PU.1. J Immunol 172:4941-4947

16. Inoguchi T, Li P, Umeda F et al (2000) High glucose level and free fatty acid stimulate reactive oxygen species production through protein kinase $\mathrm{C}$-dependent activation of $\mathrm{NAD}(\mathrm{P}) \mathrm{H}$ oxidase in cultured vascular cells. Diabetes 49:1939-1945

17. Nakayama M, Inoguchi $T$, Sonta $T$ et al (2005) Increased expression of $\mathrm{NAD}(\mathrm{P}) \mathrm{H}$ oxidase in islets of animal models of type 2 diabetes and its improvement by an AT1 receptor antagonist. Biochem Biophys Res Commun 332:927-933

18. Lacy PE, Kostianovsky M (1967) Method for the isolation of intact islets of Langerhans from the rat pancreas. Diabetes 16:35-39

19. Schrenzel J, Serrander L, Banfi B et al (1998) Electron currents generated by the human phagocyte NADPH oxidase. Nature 392:734-737

20. el-Benna J, Park JW, Ruedi JM, Babior BM (1995) Cell-free activation of the respiratory burst oxidase by protein kinase $\mathrm{C}$. Blood Cells Mol Dis 21:201-206

21. Cross AR, Jones OT (1986) The effect of the inhibitor diphenylene iodonium on the superoxide-generating system of neutrophils. Specific labelling of a component polypeptide of the oxidase. Biochem J 237:111-116

22. Suzuki Y, Ono Y, Hirabayashi Y (1998) Rapid and specific reactive oxygen species generation via NADPH oxidase activation during Fas-mediated apoptosis. FEBS Lett 425:209-212

23. Bindokas VP, Kuznetsov A, Sreenan S, Polonsky KS, Roe MW, Philipson LH (2003) Visualizing superoxide production in normal and diabetic rat islets of Langerhans. J Biol Chem 278:9796-9801

24. Cunningham G, McClenaghan NH, Flatt PR, Newsholme P (2005) L-Alanine induces changes in metabolic and signal transduction gene expression in a clonal pancreatic beta cell line and protects from pro-inflammatory cytokine induced apoptosis. Clin Sci 109:447-455

25. Fridlyand LE, Philipson LH (2004) Does the glucose-dependent insulin secretion mechanism itself cause oxidative stress in pancreatic beta-cells? Diabetes 53:1942-1948

26. Dixon G, Nolan J, McClenaghan NH, Flatt PR, Newsholme P (2004) Arachidonic acid, palmitic acid and glucose are important for the modulation of clonal pancreatic beta cell insulin secretion, growth and functional integrity. Clin Sci 106:191-199

27. Papaccio G, Graziano A, Valiante S, D'Aquino R, Travali S, Nicoletti F (2005) Interleukin (IL)-1 beta toxicity to islet beta cells: efaroxan exerts a complete protection. J Cell Physiol 203:94-102

28. Kamata H, Honda S, Maeda S, Chang L, Hirata H, Karin M (2005) Reactive oxygen species promote TNFalpha-induced death and sustained JNK activation by inhibiting MAP kinase phosphatases. Cell 120:649-661

29. MacDonald MJ (1995) Feasibility of a mitochondrial pyruvate malate shuttle in pancreatic islets. Further implication of cytosolic NADPH in insulin secretion. J Biol Chem 270:20051-20058 
30. Shimabukuro M, Zhou YT, Levi M, Unger RH (1998) Fatty acidinduced beta cell apoptosis: a link between obesity and diabetes. Proc Natl Acad Sci USA 95:2498-2502

31. El Assaad W, Buteau J, Peyot M-L et al (2003) Saturated fatty acids synergise with elevated glucose to cause pancreatic beta-cell death. Endocrinology 144:4154-4163

32. Brownlee M (2003) A radical explanation for glucose induced pancreatic beta-cell dysfunction. J Clin Invest 112:1788-1790
33. Gurgul E, Lortz S, Tiedge M, Jorns A, Lenzen S (2004) Mitochondrial catalase overexpression protects insulin-producing cells against toxicity of reactive oxygen species and proinflammatory cytokines. Diabetes 53:2271-2280

34. Lortz S, Tiedge M, Nachtwey T, Karlsen AE, Nerup J, Lenzen S (2000) Protection of insulin-producing RINm5F cells against cytokine-mediated toxicity through overexpression of antioxidant enzymes. Diabetes 49:1123-1130 